\title{
Ut pictura somnium? On A Hieroglyphic Dream by Vasari
}

\author{
Zagoury, David
}

Posted at the Zurich Open Repository and Archive, University of Zurich ZORA URL: https://doi.org/10.5167/uzh-157721

Book Section

Published Version

Originally published at:

Zagoury, David (2018). Ut pictura somnium? On A Hieroglyphic Dream by Vasari. In: Schneider, Marlen; Solte-Gresser, Christiane. Traum und Inspiration: Transformationen eines Topos in Literatur, Kunst und Musik. Paderborn: Wilhelm Fink Verlag, 57-74. 


\section{Ut pictura somnium? On a Hieroglyphic Dream by Vasari}

Sometime after 1541, the Aretine artist and scholar Giorgio Vasari (1511-1574) produced a statement on the nature of dreams. He issued his idea in graphic form

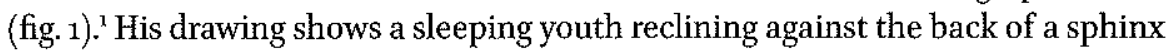
while a winged demon uses a pair of bellows to instill images into his mind. The signal originality of the picture lies in the way in which Vasari represented the fantasmi or dream images experienced by the sleeper. He did not depict the content of the dream according to the tradition, namely, naturalistically or "as it appeared"; instead he rendered it in the form of seven glyphs, aligned as if they formed a rebus. ${ }^{2}$ These glyphs, as scholars have noted, are pseudo-Egyptian in style, and a clear reference to hieroglyphics. ${ }^{3}$

Vasari produced this drawing in a period of intense discussion on the nature of dreams. ${ }^{4}$ At the time, two beliefs regarding the origin of dreams coexisted,

' On the drawing, see Florian Härb: The Drawings of Giorgio Vasari (1511-1574). Rome: Ugo Bozzi Editore, 2015, pp. 251-253, no. 109; Alessandro Cecchi in Chiara Rabbi-Bernard, Alessandro Cecchi, and Yves Hersant (ed.): Il sogno nel Rinascimento. Livorno: Sillabe, 2013, p. 184, no. 58 ; Stephanie Buck: Michelangelo's Dream. London: The Courtauld Gallery, 2010, pp. 208-211, no. 26, and its bibliography. Other discussions include: Liana De Girolami Cheney: Giorgio Vasari's Justice: Political Glory for the Farnese Family. In: Iconocrazia 10 (2016); Maurice Saß: Physiologien der Bilder: Naturmagische Felder frühneuzeitlichen Verstehens von Kunst. Berlin: de Gruyter, 2016, pp. 200-201; Roland Kanz: Die Kunst des Capriccio: kreativer Eigensinn in ReGruyter, 2016, pp. 200-201; Roland Kanz: Die Kunst des Capriccio: kreative
naissance und Barock. Munich: Deutscher Kunstverlag, 2002, pp. 167-169.

2 On the conventions for the pictorial representation of dream visions, see David Freedberg: Images dans les rêves. In: Olivier Christin and Dario Gamboni (eds.): Crises de l'image religieuse: de Nicée II à Vatican II. Paris: Éditions de la Maison des sciences de l'homme, 1999, including the references cited on p. 33, n. 2.

3 For a discussion of other Italian pseudo-hieroglyphs of the same ilk (including a very similar glyph to Vasari's in the shape of an undulating snake), see Charles Dempsey: Renaissance Hieroglyphic Studies and Gentile Bellini's Saint Mark Preaching in Alexandria. In: Ingrid Merkel and Allen G. Debus (eds.): Hermeticism in the Renaissance. Washington: Folger, 1988, pp. $342-365$.

4 The second quarter of the sixteenth century was marked by a sudden revival of what Marco Paoli called the "editorial micro-genre" of dream-books in Italy. See Marco Paoli: "Sognare nel Cinquecento. Saggio su un microgenere editoriale tra Rinascimento e Controriforma: i trattati sul sogno". In: Rara Volumina 18 (2011), issues 1-2, pp. 29-57. The period saw the publication of 


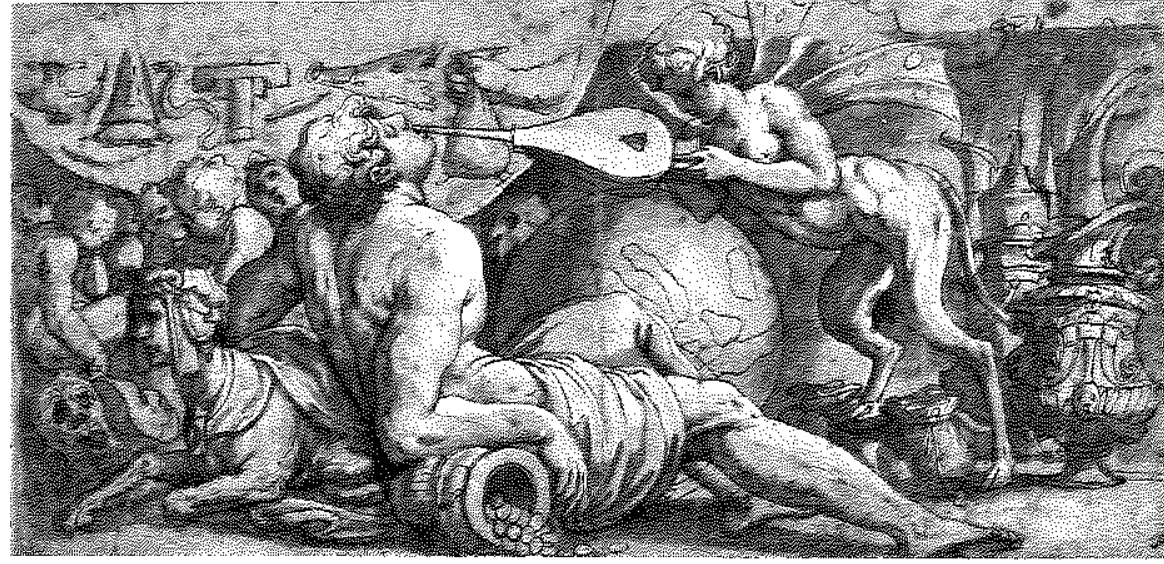

Fig. 1: Giorgio Vasari: Allegory of a Dream. Pen and brown ink, heightened with white, on blue paper, $19,2 \times 39,4 \mathrm{~cm}$ (ca. 1541-1545).

despite being partly contradictory. On the one hand, scholars promoted physiological explanations for the phenomenon of oneiric experience, regarding it as a residual activity of the imagination whereby past sensory impressions are rekindled while the body is at rest. On the other hand, Renaissance culture held on to the ancient belief that dreams were the manifestation of a message, omen or revelation, and the result of some external influence. ${ }^{5}$ Vasari's drawing, interestingly, speaks to both conceptions of dreaming. The picture highlights the

important scholarly works on the subject: the Italian translation of the Somnia Danielis (Insonnio del Daniel, completed 4525); a Latin translation of Artemidorus' Oneirocritica (De somniorum interpretatione, 1539); Agostino Nifo's commentary on Aristotle's De somno et vigilia (1527) J. C. Scaliger's commentary on Hippocrates' De insominiis (1539) and, outside of Italy, Auge Ferrier's imposing Liber de somniis (1549). Alongside these, a flurry of literary works concerned with dreams appeared, notably: Ercole Bentivoglio, Il sogno amoroso (1530); Lodovico Dolce,

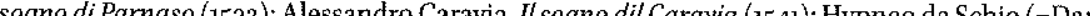
(e) Baro) Predica Gelli's Capricci del Bottaio (1546); and the 'Sogni' in Anton Francesco Doni's Foglie della Zucca $\left(155^{2}\right)$. On dream culture in the Cinquecento more broadly, see in particular Francesco Gandolfo: Il "Dolce Tempo": mistica, ermetismo e sogno nel Cinquecento. Rome: Bulzoni, 1978; An thony Grafton: Reforming the Dream. In: Christopher S. Celenza and Kenneth Gouwens (eds.) Humanism and Creativity in the Renaissance: Essays in Honor of Ronald G. Witt. Leiden: Brill, 2006, pp. 271-292; Peter Burke: The Cultural History of Dreams. Varieties of Cultural History. Ithaca, N.Y.: Cornell University Press, 1997, pp. 23-42.

5 In the sixteenth century we find interesting signs of a growing critical rejection of the view of dreams as prophecies. In his De vanitate, which first appeared in Italian translation in 1547 , Heinrich Cornelius Agrippa von Nettesheim deploys a sneering critique against oneirocriticism. For him, dreams are merely irrational miscarriages of the fantasia; oneiromancers are not to be taken seriously. The book was featured in the Louvain Index in 1546 . See Heinrich Cornelius Agrippa: Della vanità delle scienze. [De incertitudine et vanitate scientiarum et ar- physicality of the phenomenon by foregrounding the body of the sleeper in all its nudity; reclining in the manner of Michelangelo's figure of Night in the Medici chapel (which certainly served as a source for Vasari's design), the youth's sensual anatomy fills most of the pictorial space. ${ }^{6}$ Yet the composition also reflects the archaic, prophetic understanding of dreams, as the devil literally inspires the night vision to the sleeper. The mantic conception of dreaming also resonates with the pseudo-Egyptian glyphs standing for the sleeper's phantasms. ${ }^{7}$ This dream, rather than a lifelike experience, takes the form of a sequence of signs - a cryptic text. To this day, its signification has not been elucidated with certainty. ${ }^{8}$

Our essay will focus on a question that scholars, in attempting to solve this riddle, have largely overlooked: how and why did Vasari come to propose that dreams could have a hieroglyphic form? And what relation does this iconography bear to the Renaissance appraisal of the Egyptian script? The question is of particular interest if we recall that the notion of "hieroglyphic dream" was central to the modern revival of dream interpretation at the turn of the twentieth century. In his Traumdeutung (1900), Sigmund Freud proposed that dreams were given to us in a Bilderschrift. ${ }^{9}$ In 1913 , he added: "If we reflect that the means of representation in dreams are principally visual images and not words, we shall see that it is even more appropriate to compare dreams with a system of writing than a language. In fact, the interpretation of a dream is completely analogous to the decipherment of an ancient pictographic script such as Egyptian hieroglyphics $[\ldots . .]^{p 10}{ }^{\circ}$ Carl Gustav Jung made the same affirmation, specifying that the

tium], Transl. by Lodovico Domenichi. Venice: Giovanni Farri \& fratelli, 1547, chap. 39, titled "Della somnispicia".

6 Buck: Michelangelo's Dream, p. 208. The relationship with Michelangelo's Night is confirmed by the presence of the owl in the background.

On the iconography of dream images, see Freedberg: Images dans les rêves, and his references.

8 The only interpretation was made by Julian Kliemann in 1981. Kliemann proposed that the glyphs should stand for the seven deadly sins: from left to right, he identified wrath (oil lamp, by extension, fire), sloth (turtle carrying an obelisk), envy (snake), pride (castle upside down) gluttony (boar), avarice (money bag). However, as Kliemann himself admits, the interpretation is not entirely satisfactory. Lust is missing, and the fifth symbol from the left (a stylus or pencil?) could not be interpreted. See Julian Kliemann in Laura Corti and Margaret Daly Davis: Giorgio Vasari: principi, letterati e artisti nelle carte di Giorgio Vasari. Florence: Casa Vasari 1981, p. 173 .

9 Sigmund Freud: The Basic Writings of Sigmund Freud. Transl. by A. A. Brill. New York: The Modern Library, 1938, p. 319. In this translation, "Bilderschrift" was rendered as "in hieroglyphics". The original edition of Brill's translation (The Interpretation of Dreams, New York, Mac Millan, The original edition of Brill's translation (The Interpretation of Dreams, New York, Mac Millan,
1913, p. 260) read "picture-writing" instead of "hieroglyphics". The later standard translation by James Strachey et al. proposes "in a pictographic script". See: The Standard Edition of the Complete Psychological Works of Sigmund Freud. Ed. by James Strachey et al. Transl. by James Strachey. London: Vintage, 2001, vol. IV, p. 277.

to The Standard Edition of the Complete Psychological Works of Sigmund Freud. Transl. by James Stachey, vol. XIII, p. 177. 
method common to both oneiric and hieroglyphic decipherment was "amplification".11 One dream in particular became emblematic of the modemist imagination: the "rêve hiéroglyphique" experienced by Charles Baudelaire in 1856 , which convinced the poet that dreams were "an almost hieroglyphic language" to which he "did not possess the key". ${ }^{2}$ Baudelaire's account of it prompted many commentaries, notably the experimental exegesis of Michel Butor, who sought to provide us with the said "key". ${ }^{13}$ How did Vasari come to share this fundamental intuition?

At first glance, Vasari's treatment of the subject does not chime with the dominant understanding of Egyptian symbolism in the early sixteenth century. For Giovanni Pico della Mirandola, Marsilio Ficino and the furst generation of emblem theorists, hieroglyphs were regarded as synthetic pictorial expressions of universal and immutable truths. ${ }^{14}$ They were also considered a holy language (hiero- meaning sacred) embodying principles of ancient wisdom (prisca sapientia). Taking his cue from Plotinus, Ficino posited that hieroglyphs (although still misunderstood at the time) encapsulated information about the essence of things, rather than the superficial or transient. The context in which Vasar places them - in the slumbers of a profligate youth surrounded by worldly temptations, fumes and the mask of ugliness, and imparted by what looks like a succubus - is at odds with this idealist Neoplatonic view. ${ }^{15}$ The composition is all

" C. G. Jung: Analytical Psychology: Its Theory and Practice: the Tavistock Lectures. Ed. by E. A. Bennet, Mary Barker, and Margaret Game. London: Routledge \& Kegan Paul, 1968, p. 93. Jung characterized amplification as the act of "seeking parallels".

12 See Baudelaire's letter of 13 March 1856 to Charles Asselineau, in Charles Baudelaire: Correspondance. Ed. by Claude Pichois and Jean Ziegler. Paris: Gallimard, 1973, vol. II, p. 338. On Baudelaire's conception of hieroglyphs, see Patrick Labarthe: Baudelaire et la tradition de l'allégorie. Genève: Droz, 1999.

${ }^{13}$ Michel Butor: Histoire extraordinaire. Essai sur un rêve de Baudelaire. Paris: Gallimard, 1961. The starting point of Butor's exegesis is a challenge to Baudelaire's alleged enigma, appropriating the poet's "je": "Un language dont je n'ai pas la clef. Un language dont il nous donne les clefs" (p. 19).

${ }^{24}$ On the early understanding of hieroglyphs, see notably the Introduction to: Horapollo: The Hieroglyphics of Horapollo. Ed. by George Boas. Princeton: Princeton, 1993, chap. 5 and chap. 10; Brian A. Curran: The Egyptian Renaissance: The Afterlife of Ancient Egypt in Early Modern Italy. Chicago \& London: University of Chicago Press, 2007; Karl Giehlow: The Humanist Interpretation of Hieroglyphs in the Allegorical Studies of the Renaissance with a Focus on the Tripretation of Hieroglyphs in the Allegorical Studies of the Renaissance with a Focus on the Tri-
umphal Arch of Maximilian I [1915]. Transl. by Robin Raybould. Leiden \& Boston: Brill, 2015 .

15 Scholars regard the bellowing demon as having been borrowed from Albrecht Dürer's so-called Dream of the Doctor, another work that certainly deals with worldly temptations. It is not certain that this demon was meant by Vasari as a specific type such as the incubus or the succubus - which would have made his drawing an exceptionally early treatment of the question of nightmares. Rather when Vasari recorded Dürer's print he described the bellowing demon simply as "il diavolo". See Giorgio Vasari: Le vite de' pily eccllenti pittoni, scltorie architeton, elle redaioni del 550 . 1966 vol. V p. 4. Onjo in 1966, vol. V, p. 4. On incubi in Renaissance art, see Patricia Simons: "The Incubus and Italian Renaissance Art". In: Source: Notes in the History of Art 34 (2014), issue 1; Charles Dempsey: the more surprising if we recall that Vasari was steeped in this learned culture of symbolism. ${ }^{16}$ His drawing, then, may potentially be regarded as a critique. ${ }^{17} \mathrm{Ju}-$ lian Kliemann mitigated the tension by suggesting that Vasari's pictograms could stand for the seven deadly sins. ${ }^{18}$ More recent readings associated the drawing with capricci and with alchemy. ${ }^{19}$ Yet the tension remains.

With this essay, I propose to shed light on the matter by tracing the elusive affinity between dreams and ancient scripts in the intellectual culture of mid-Cinquecento Italy. I hope to show that the presence of this trope in the Aretine's work sheds new light on the Traumkultur of his time as well as on the originality of his drawing.

\section{Valeriano'ṣ Oneiric Philology}

We may begin by pointing out that the pictorial device employed by Vasari to make the sleeper's phantasms visible is unusual. It is very unlike the smoky "first cloud of sleep"2o in which most dream visions are represented in the Renaissance, being closer to a neat semi-circular disk. One scholar compared it to a "kind of speech bubble", which would make it an interesting anticipation of the signal convention of comic book visual culture. ${ }^{21}$ Given its association with the pair of bellows, it is worth considering the possibility that the shape may actually stand for a bubble, or bulla. Vasari would thus be elaborating on the emptiness of dreams by reference to the famous homo bulla adage revivified by Erasmus. Thereby he would be expressing how dreams are, as Cinquecento Florentines

Inventing the Renaissance Putto. Chapel Hill, NC: University of North Carolina Press, 2001, pp. 107-146.

16 On Vasari's culture of symbolism, see Antonella Fenech Kroke: Giorgio Vasari: la fabrique de l'allégorie. Florence: L. S. Olschki, 2011.

${ }_{17}$ The same kind of critique voiced by Agrippa in the De vanitate. See footnote 5 above.

18 See footnote 8 above.

19 Ekkehard Mai (ed.): Das Capriccio als Kunstprinzip: zur Vorgeschichte der Moderne von Arcimboldo und Callot bis Tiepolo und Goya. Vienna and Milan: Kunsthistorisches Museum Wien and Skira, 1996, p. 216, no. 26; Kanz: Die Kunst des Capriccio, pp. 167-169; Saß: Physiologien der Bilder, pp. 200-201.

${ }_{20}$ Macrobius: Commentary on the Dream of Scipio. Transl. by William Harris Stahl. New York New York, 1966, III, 7, p. 89. On this, see Christine Göttler: Vapours and Veils: The Edge of the Unseen. In: Christine Göttler and Wolfgang Neuber (eds.): Spirits Unseen: The Representation of Subtle Bodies in Early Modern European Culture. Leiden: Brill, 2008, pp. xv-xxvii. On conventions for the representation of dreams, see footnote 2 above.

${ }^{21}$ Julian Kliemann in Corti and Davis: Giorgio Vasari: principi, letterati e artisti nelle carte di Giorgio Vasari, p. 173, spoke of "una specie di fumetto"; Alessandro Cecchi in Rabbi-Bernard, Cecchi, and Hersant: 11 sogno nel Rinascimento, p. 184, remarked "come in un 'fumetto". 
would say, cose in aria (groundless things, "full of air"). ${ }^{22}$ The bubble is also interesting because it marks the boundary between the figurative space of the sleeper and the textual or glyphic space of his night vision. The picture-within-a-picture constituted by the dream inaugurates a leap into a different semiotic mode. In Peircian terms, it allows two different regimes to cohabit in the same image: the iconic (the sleeper's world, represented naturalistically) and the symbolic (his glyphic dream). It testifies to Vasari's belief that dreams fundamentally differ in nature from the visible world in that they have a semantic content, being, as Hippocrates affirmed in his canonical characterization of dreams (Regimen, 4, 86), a "sign" ( $\varepsilon x \mu \eta p i ́ \omega v)$.

It is through this semiotic approach to dreaming that we shall make our first foray into the drawing's unusual vocabulary. Indeed, it appears that this textual understanding of dreams was of relevance to some of the Renaissance philologists who pioneered the research on ancient Egyptian hieroglyphics. We find an early trace of this in the writings of Pierio Valeriano Bolzano, one of the most influential of these researchers, whom Vasari knew personally. In his magnum opus of hieroglyphic studies, the Hieroglyphica (1556), Valeriano relates an important debate on the question of the applicability of dream-books for the elucidation of hieroglyphs. The discussion, in which he had participated in person, took place one evening in 1522 at the house of his uncle Fra Urbano in Venice. It involved Leone Leoniceno, Leonico Tomeo and Daniele Ranieri - all humanists of the circle of Aldus united by their desire to uncover the meaning of the ancient Egyptian script. ${ }^{23}$ In the course of the discussion, Leoniceno explained that the doctrine of dream interpretation has the same origin and epistemic value as Egyptian wisdom. Therefore, he argued, oneirocriticism may be used to supplement the insufficient textual sources for the decipherment of hieroglyphs, ${ }^{24}$ citing Hippocrates - whose semiotic conception of dreams we mentioned earlier - as an example. In response, Ranieri deeply thanked his friend for this insight, admitting he had felt "titillated" by the desire to invoke dreams throughout their philological debate on hieroglyphics. ${ }^{25}$

22 Vocabolario degli Accademici della Crusca. Venice: Giovanni Alberti, 1612, 'aria'. "in aria", senza fondamento.

${ }^{23}$ On this episode, see Giehlow: The Humanist Interpretation of Hieroglyphs, pp. 203-205.

${ }^{24}$ "...respondit Leonicenus, Ægyptionum argimentum hoc latissime diffundi posse. $\mathrm{Nam} \& \mathrm{He}$ trusconum doctrinam de prodigijs, \& ipsa Onirocriticarum commenta cum physica magna sui parte sint, ab Ægyptijs emanasse crediderim". Pierio Valeriano Bolzani: Hieroglyphica sive de sacris Aegyptionum literis commentarii. Basel: Michael Isengrin, 1556, Liber XXXIII, p. 236r.

25 "Tum Ranerius: Habendæ mihi sunt tibi Leonicene gratiæ non uulgares, qui coniectores mihi chariores esse facis, dum eos Ægyptiacum quid sapere docueris, quibus sum ab ineunte æatate mirifice delectatus. Dumque Vrbanus, atque mox Thomæus loquerentur, titillabat me cupiditas quædam, ut ad ea qua dicebant, de somnijs quædam non incogrua subijcerem [sic]". Bolzani: Hieroglyphica. Liber XXXIII, p. $236 \mathrm{r}$.
It was in the company of Valeriano that Vasari would have been exposed to this first instance of dream-hieroglyph metaphor. Indeed, as a child Vasari was apprenticed to Valeriano in Florence. Around 1524, he even had the privilege of attending the great scholar's Latin classes in the company of the young princes Ippolito and Alessandro de' Medici for two hours daily. ${ }^{26}$ This pupillage started two years after Valeriano assisted in the discussion between his uncle and Leoniceno, Tomeo and Ranieri. It is likely that the master recounted it to his disciples, thereby enlightening the young Vasari on this particular property of dream imagery. In any case, the episode undoubtedly left a mark on Valeriano, who deemed the dialogue worthy of being recorded in his Hieroglyphica. He also proceeded to make ample use of oneirocritical material in the book, relying on Artemidorus and Synesius, and frequently quoting the conjectores (oneiromancers) "whom we welcome in our company, since their lessons have much similitude with Egyptian hieroglyphs". ${ }^{27}$ Dream-books lent themselves to his philological enterprise because they often gave the symbolic meaning of specific animals, plants or objects without reference to the context in which they had to appear. Most importantly, the symbolisms were premised on the principle of allegory, namely, the assumption that the sign does not stand for what it represents or looks like (idem per idem reference) but for something else, and in a non-obvious way (allos in allegoria meaning 'other').$^{28}$ This was also presumed to be the way in which the symbolism of hieroglyphs functioned. ${ }^{29}$

The idea that dreams were a medium for the revelation of deeper truths must have lent additional credence to this form of cross-disciplinary philology. One Renaissance poem even suggested that sleep could yield the keys to the decipherment of hieroglyphs.

Ecco l'alta Colonna che sostenne

Quel bel typo di memoria antica

Ogni figura, ogni mole, \& fabrica

Et varie foggie di segni contenne

$[\ldots]$

${ }^{26}$ Vasari: Le vite, vol. V, p. 515 .

${ }_{27}$ "Conjectores (nam libenter hos in comitatum accipimus, quod eorum dictata magnum cum Aegyptiacis hieroglyphicis similitudinem habent)...". Bolzani: Hieroglyphica. Liber XXXII, p $230 \mathrm{ov}$

${ }_{28}$ Despite its difficulty, the fundamental essay on Renaissance cultures of allegory remains Ernst H. Gombrich: Icones symbolicae: Philosophies of Symbolism and Their Bearing on Art. Symbolic Images. London: Phaidon, 1972, pp. 123-199.

29 On the relation between ideogrammatic and phonetic symbolism in sixteenth-century under-

on the relation between ideogrammatic and phonetic symbolism in sixteenth-century understanding of hieroglyphs, see Claude-François Brunon: Signe, figure, language: les Hieroglyphica
d'Horapollon. In: Yves Giraud (ed.), L'Emblème à la Renaissance. Paris: Société d'Edition d'Enseignement Supérieure, 1982, pp. 29-47 
In breve sogno tutto qui s'explica

In sogno intendo ch'a l'autor avenne

Behold the high column that sustains

that lovely type of ancient memory

Every figure, every grand structure and building,

and various shapes of signs herein contained

[...]

is here all in a brief dream explained,

In a dream that appeared to the author, I understand ${ }^{30}$

The cryptic sonnet was published anonymously in 1546 as an epigraph to the first French translation of the Hypnerotomachia Poliphili (1499), the famous ac count of Poliphilio's dream in which the hero repeatedly stumbles upon classical monuments bearing complex hieroglyphic inscriptions. Its ode to a "high column" bearing "figures" and "all kinds of signs" is a clear allusion to an obelisk, the meaning of which, says the sonnet, is "in a brief dream all explained". ${ }^{13}$ The author of the text is not known, but it has been attributed to Giovanni Pico della Mirandola, who had a keen interest in both hieroglyphs and doctrines of revelatory dreaming (notably Averroes' copulatio theory)..$^{32}$

Both the Hypnerotomachia and its new epigxaph illustrate the elusive affinity between dreaming and reading (or the inability to read) hieroglyphs. They encapsulate how a peculiar virtue of oneiric experience, that of reconnecting us with lost memories, became emblematic of the Renaissance's perplexing quest to recover the lost knowledge of antiquity. Sleep was a space of superterrestrial encounters; but it was a space of supertemporal ones as well - encounters with the future (in prophetic dreams) but also with the past, with our ancestors (as in Scipio's famous somnium) and eventually with classical lore.

30 Hypnerotomachie, ou, Discours du songe de Poliphile. Paris: Jacques Kerver, 1546, epigraph; translation (with my emendation) from: Maria Ruvoldt: The Italian Renaissance Imagery of Inspiration. Cambridge: Cambridge University Press, 2004, p. 205, n. 61.

${ }^{31}$ This Colonna is also a reference to the Hypnerotomachia's purported author, Francesco Colonna. The column is called a "fine type of ancient memory" (bel typo de la memoria antica) Although at first glance typo means sort or kind, it may be a double entendre also refering to. typeface and, by extension, a writing system. "ypeface and, by extension, a writing system. Maria Ruvoldt already suggested that these 32 "signs" might be hieroglyphs. See The Italian Renaissance Imagery of Inspiration, p. 205, n. 61. Above the sonnet is the inscription "G. P. M." On Pico's reaction to Averroes' theories of divinatory sleep, see Guido Giglioni: Phantasms of Reason and Shadows of Matter: Averroes's Notion of the Imagination and Its Renaissance Interpreters. In: Anna Akasoy and Guido Giglioni (eds.): Renaissance Averroism and its Aftermath: Arabic Philosophy in Early Modern Europe. Dordrecht: Springer, 2013, pp. 173-193.
II The Artistic Hieroglyph: Grylloi, Grotesques, Fantasia

Besides this concrete association of dreams with hieroglyphs in his immediate intellectual environment, Vasari may have known other, more imperceptible incursions of this metaphor in sixteenth-century artistic culture. These incursions are rarely explicit, manifesting mainly in acts of ekphrasis or recognition namely, in the ways people described and identified (or, rather, misidentified) images and symbols.

It is sometimes overlooked that the Renaissance artist's means of accessing hieroglyphs first-hand was not limited to viewing the obelisks of Rome. Such symbols could also be found on gems and cameos. Florence had one of the most important concentrations of gems, thanks to the collection of Lorenzo de Medici, who prized these amulets purported to have magical powers. ${ }^{33}$ Many of these stones were associated with Egypt and their virtues linked to the glyphs they carried..$^{34}$ One particular kind of apotropaic amulet bore figures today known as grylloi, but also called chimere at the time - a word that could also be synonymous with sogno. ${ }^{35} \mathrm{~A}$ gryllos was typically a hybrid creature composed of different animal and human parts, such as the Hippalektryon, or part-horse part-rooster hybrid, sometimes with a human face as a chest (fig. 2). ${ }^{36}$

In principle, these cameos did not have anything to do with the act of sleeping. Yet their imagery was frequently associated with dreams, or it inspired pictorial motifs, which were interpreted in this way. The fantastical figures of Hieronymus Bosch provide an example of this phenomenon. Over fifty years ago, Jurgis Baltrušaitis convincingly showed that Bosch sourced some of his monsters from these allegedly Egyptian glyphs (fig. 3). ${ }^{37}$ When they were first viewed in Italy,

33 See Patricia Aakhus: Astral Magic in the Renaissance: Gems, Poetry, and Patronage of Lorenzo de' Medici. In: Magic, Ritual, and Witchcraft 3 (2008), issue 2, pp. 185-206; Erika ZwierleinDiehl: Antike Gemmen und ihr Nachleben. Berlin, New York: de Gruyter, 2007; Simone Michel: Diehl: Antike Gemmen und ihr Nachleben. Berlin, New York: de Gruyter, 2007; Simone Michel:
Die Magischen Gemmen. Zu Bildern und Zauberformeln auf geschnittenen Steinen der Antike und Neuzeit. Berlin: Akademie Verlag, 2010. For a brief overview of Lorenzo's collection, see Antonio Giuliano, Nicole Dacos, and Ulrico Pannuti (eds.): Il tesoro di Lorenzo il Magnifico: Le gemme. Florence: Sansoni, 1973.

34 The most important example of semi-precious intaglio in Lorenzo's collection was the Tazza Farnese, which bears a sphinx and an unmistakable allegory of the Nile.

35 On grylloi, see Kenneth Lapatin: Grylloi. In: Christopher Entwistle and Noël Adams (eds.): Gems of Heaven: Recent Research on Engraved Gemstones in Late Antiquity, c. AD 200-600. London: British Museum, 20u, pp. 88-98. The near-synonymy of sogno and chimera can be observed, for example, in the writings of Anton Francesco Doni, and most notably in his Disegno (1549) and his Pitture (1564). The mythological Chimera, by extension, began to mean "fantastical creature", impossibilium/adynaton, fiction, absurdity.

${ }^{36}$ Entwistle and Adams: Gems of Heaven, p. 189; Paolo Vitellozzi: Gemme e magia dalle collezioni del Museo archeologico nazionale dell'Umbria. Penugia: Fabrizio Fabri Editore, 2010, pp. $134-136$.

37 Jurgis Baltrušaitis: Le Moyen Âge fantastique. Antiquités et exotismes dans l'art gothique. Paris: A. Colin, 1955, fig. 26. 


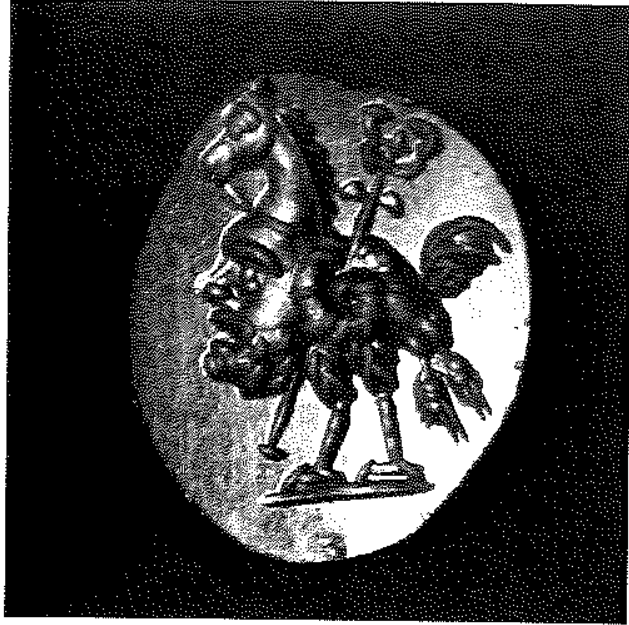

Fig. 2: Cameo engraved with a Hippalektryon. Green jasper, $1,26 \times 1,05 \times 0,2 \mathrm{~cm}$ (1 st-2nd century A.D.)
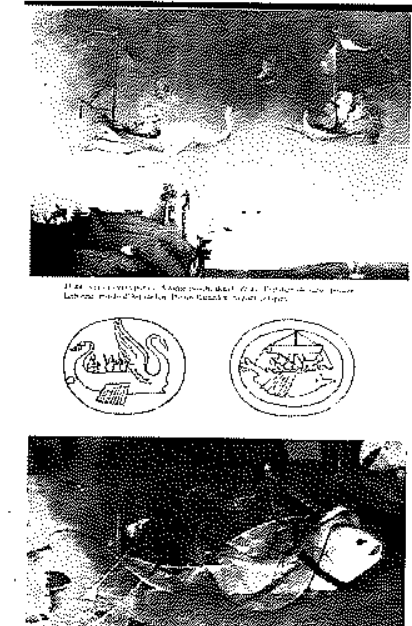

Fig. 3: The figs. $43-44$ of Jurgis Bailrusaitis's Le Moyen-Âge fantastique (1983), p. 61 .

Bosch's drolleries, on top of having been called "grillo" by Don Felipe de Guevara, ${ }^{38}$ were identified with dreams, being called "sogni" or "somnia". ${ }^{39}$ The association must have become customary, because the Italian iconography of nightmare apparitions also began to draw on this very imagery. It is striking that in Marcantonio Raimondi's so-called Dream of Raphael and in Battista Dossi's Night (fig. 4), the haunting phantasms were composed using the same strategies as the engraved Hippalektrya. In Dossi's nightmare in particular, the assemblage of facial torsos and chickens' limbs characteristic of the grylloi is evidently the guiding principle behind the making of the little monsters Dominique Cordellier once called "volailles oniriques" (oneiric poultry). ${ }^{40}$ In fact, hieroglyphic cameos had already come into contact with the theme of dreams in the pages of the $H y$ pnerotomachia Poliphili. One of the symbols encountered by Poliphilio displays a coin or amulet bearing half-elephant and half-ant figures (fig. 5), which cannot but recall similar intaglio glyphs that would have circulated at the time, in par-

${ }_{38}$ Lapatin: Grylloi, p. 9o. Note, however, that Lapatin has "found no evidence of the term gryllos applied to ancient gems depicting hybrids, rather than caricatures, before the 18 th century" (p.

Walter S. Gibson: Bosch's Dreams: A Response to the Art of Bosch in the Sixteenth Century. In: The Art Bulletin 74 (1992), issue 2, pp. 205-218.

${ }^{4}$ Dominique Cordellier: Esquisse d'un portrait de l'artiste maniériste en génie du sommeil. In: Philippe-Alain Michaud (ed.): Comme le rêve le dessin: dessins italiens des XVIe et XVIYe siècles du Musée du Louvre. Paris: Centre Pompidou \& Musée du Louvre, 2005, p. 143

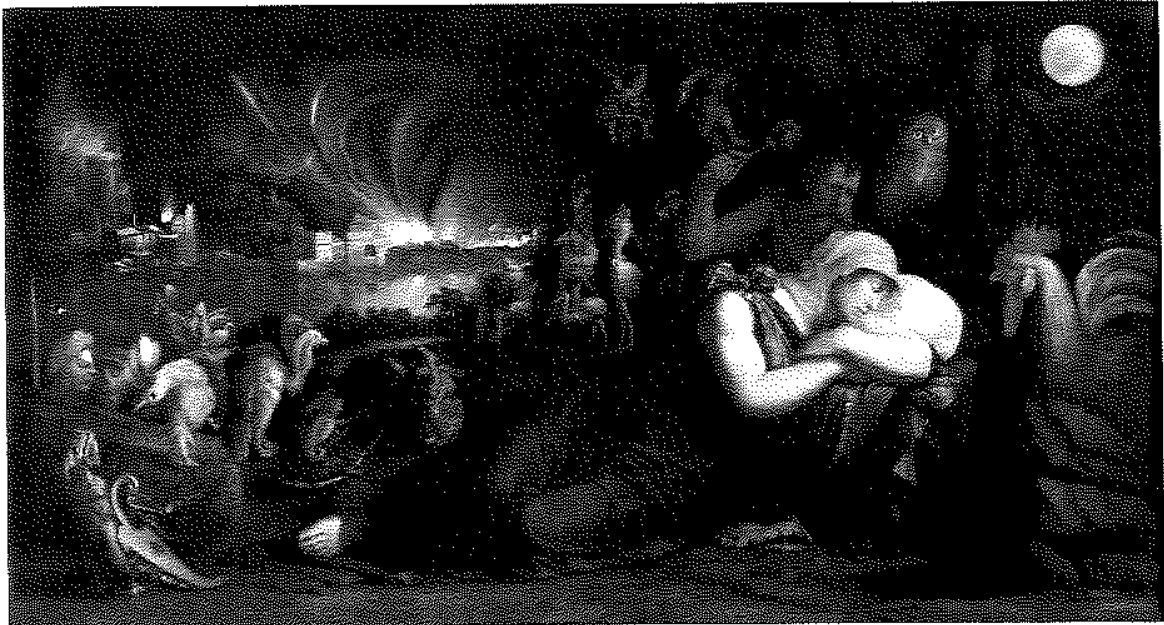

Fig. 4: Battista Dossi: The Night. Oil on canvas, $82 \times 149,5 \mathrm{~cm}$ (1544).

ticular the half-elephant and half-shell gryllos (fig. 6). ${ }^{41}$ I must leave open the complicated question of the concrete transmission of these designs and the role of potential intermediates (such as manuscript marginalia). My suggestion is that Vasari may very well have been aware of the (allegedly) Egyptian and highly symbolic nature of these motifs. Ultimately, his "hieroglyphic dream" could be his own erudite attempt to revisit the origin of this clandestine transmission of forms.

A similar conflation of dreams and hieroglyphs manifests itself in the way Vasari's contemporaries interpreted the recently discovered "grotesque" ornament of ancient Rome. As is well known, grotesques were frequently compared to dreams being called "sogni della pittura" (D. Barbaro), "sogni", "chimere" (A. F. Doni) or "come de insogni" (P. Ligorio).$^{42}$ The association is also implicit in a number of ornamental compositions, which display a sleeper at their center surrounded by grotesque designs and creatures. ${ }^{43}$ Some authors, including the artist and archaeologist Pirro Ligorio, regarded grotesques as a kind of hieroglyph, convinced as they

${ }_{41}$ Baltrušaitis: Le Moyen Âge fantastique, fig. 23; Hypnerotomachia poliphili. Venice: Aldus Manutius, 1499 , p. p-viv.

${ }_{42}$ Daniele Barbaro: I dieci libri dellarchitettura [1567]. In: Paola Barocchi (ed.): Scritti d'arte del Cinquecento. Milan, Naples: Riccardo Ricciardi Editore, 1971, vol. III, p. 2634. A. F. Doni: DiCinquecento. Mnl Barochi: Scritti d'arte del Cinquecento, vol. I, p. 585; Pirro Ligorio: Libro de segno [1549]. In: Barocchi: Scritti d'arte del Cinquecento, vol. I, p. 585; Pirro Ligorio: Libro de antichita. In: Barocchi: Scritti d'arte del Cinquecento, vol. III, p. 2668. Barbaro's definition was
the starting point of Gian Paolo Lomazzo's reflections on grotesques. See Lomazzo: Trattato [1585]. In: Barocchi: Scritti d'arte del Cinquecento, vol. III, p. 2692.

43 Philippe Morel: Les grotesques. Paris: Flammarion, 1997, p. 97; Carsten-Peter Warncke: Die ornamentale Groteske in Deutschland, 1500-1650. Berlin: V. Spiess, 1979, Vol. II, no. 1100 


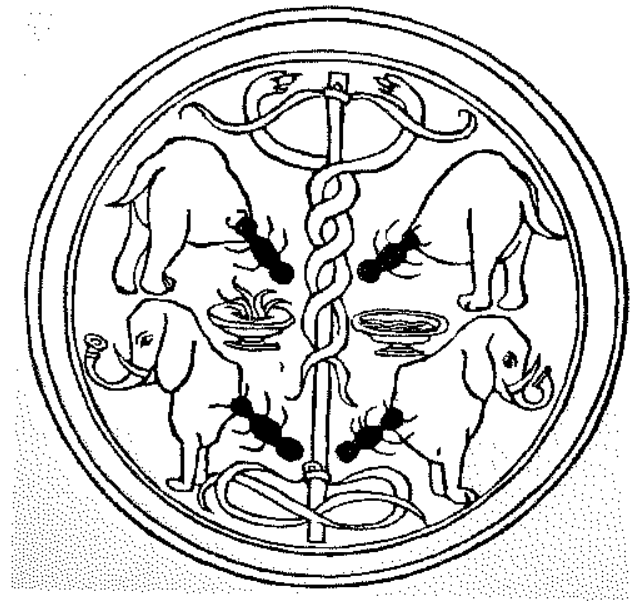

Fig. 5: Illustration from Hypnerotomachia poliphili (1499), p. p-viv.

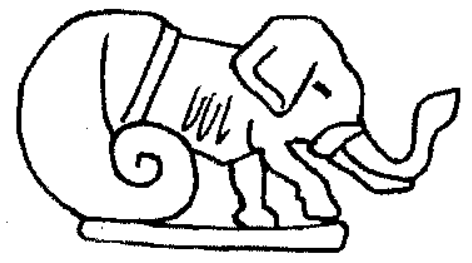

Fig. 6: Ancient cameo reproduced in Jurgis Baltrusaitis's Le Moyen-Âge fantastique (1983), described as "Bêtes antiques dans la coquille".

were that the figures were a text in disguise, concealing a hidden signification. ${ }^{4}$ Gian Paolo Lomazzo, for example, compared grotesques to "figure egizzie, dimandate ieroglifici" because he thought they could "express things and ideas not with the things themselves, but through other figures" - that is to say, by way of allegory. ${ }^{45}$ Some authors suggested that grottesche should be called "cryptics". Indeed, they were found in grottoes, in other words in "crypts", and their meaning was as obscure as their home. ${ }^{46}$

There is, finally, a third potential reason behind Vasari's association of hieroglyphs with dreams. In the Renaissance, as we briefly explained in our introduc tion, dreams were thought to emerge from the faculty of imagination, also called fantasia, following the views of Aristotle and the medical tradition. ${ }^{47}$ In the same

44 Barocchi: Scritti d'arte del Cinquecento, vol. III, p. 2676. Cristina Acidini Luchinat saw the premises of this association in Pinturicchio's decorations for the Appartamento Borgio in the Vatican, in Filippino Lippi's style of grotesque ornament, or in Parentino's painted candelabra in the Chiostro di Santa Giustina, Padua (now lost). See Cristina Acidini Luchinat: La grottesca. In: Giulio Bollati and Paolo Fossati (eds.): Storia dell'arte italiana. Turin: Giulio Enaudi vol. 4, pt. 3, pp. 170-172.

45 Lomazzo: Trattato, p. 2692 and p. 2694: “...esprime le cose ed i concetti non con le proprie, ma con altre figure" (the italics are mine).

${ }^{4}$ Dorothea Scholl: Von den "Grottesken" zum Grotesken: die Konstituierung einer Poetik des Grotesken in der italienischen Renaissance. Münster: Lit, 2004, p. 15, n. 2.

See, for example, De anima, 3, 3, 428a5-8. The other relevant passages are discussed in the Introduction to: David Gallop (ed.): Aristotle on Sleep and Dreams. Warminster: Aris \& Phillips, 1996.

way, in Vasari's day, grotesques were typically regarded as pure products of the imagination, and often termed fantasie. Yet in Vasari's system of the arts, the imagination was also the locus of disegno, the artist's mental act of conception..$^{48}$ In recent years, scholars have sought to reconsider Vasari's theory of disegno by expounding it as a form of graphic expression that partakes of immutable archetypes, thereby likening it to early modern doctrines on the semantics of ancient and holy languages. Charles Dempsey, for example, compared Vasari's notion of disegno with contemporary conceptions of universal Logos, and Matteo Burioni highlighted the affinities it shares with coeval views on hieroglyphics. ${ }^{49}$ In this light, we may also regard Vasari's Dream drawing as a statement on the true nature of the objects of the imagination, their universality and immutability, as well as their potentially demonic origin. ${ }^{50}$ His drawing, then, would be a variation on the idea of a glyphic, cryptic sogno di pittura.

\section{Conclusion}

The nexus between dreams and hieroglyphs, woven deep into the fabric of Cinquecento intellectual culture, could have been explored through many other lenses - from teratomancy to alchemy, through emblematics..$^{51}$ Our reflections focused on the context of the making of Vasari's drawing; yet the elective affinity between oneiric images and textual glyphs forms an elusive undercurrent running through Western culture since antiquity. It aroused the interest of scholars such as Jacques Derrida and Aleida Assmann, and before that it surfaced in the writings of Bishop William Warburton, E.T.A. Hoffmann and Gotthilf Heinrich von Schubert. ${ }^{52}$ Its ubiquity and diversity, even in the Cinquecento, is such that

$4^{8}$ The disegno is also called "concetto imagined in the mind" ("...esso disegno altro ni sia che una apparente espressione e dichiarazione del concetto che si ha nell'animo, e di quello che altri si è nella mente imaginato e fabbricato nell'idea", Vasari: Le vite, vol. I, p. m11). Benvenuto Cellini similarly wrote that the mental disegno is conceived "in the Immaginativa".

49 Charles Dempsey: Disegno and Logos, Paragone and Academy. In: Peter M. Lukehart (ed.): The Accademia Seminars: The Accademia di San Luca in Rome, c. 1590-1635. CASVA seminar papers. New Haven and London: Yale University Press, 2010, p. 43; Matteo Burioni: Giorgio Vasaris Vite. In: Wolfgang Brassat (ed.): Handbuch Rhetorik der Bildenden Künste. Berlin: de Gruyter, Vite. In: Wolf, p. 275

50 On the demonic origin of artistic inspiration, see Michael Cole: "The Demonic Arts and the Origin of the Medium". In: The Art Bulletin 84 (2002), issue 4, pp. 621-640.

${ }^{51}$ The common trait of all of these is a fundamental involvement in allegory, or the summoning of otherness through signs.

${ }_{53}$ Jacques Derrida: Writing and Difference [1978]. Transl. by Alan Bass. London: Routledge, 200I pp. 258-278 (chap. 7: "Freud and the Scene of Writing"); Aleida Assmann: Traum-Hieroglyphen von der Renaissance bis zur Romantik. In: Gaetano Benedetti and Erik Homung (eds.): Die Wahrheit der Träume. Munich: Fink, 1997, pp. 119-144. 
it is hard to identify with precision where Vasari's hieroglyphic metaphor in the Allegory of a Dream was sourced. Its appearance in a work of visual art, however, is a rare occurrence, which marks out the drawing as an original contribution to the iconography of dream images. Through it, the Aretine does not solely shroud his dream in mystery. He also invites us to consider the independent ontology of phantasms and their fundamental irreducibility to natural vision. He affirms their quiddity: as ideograms, ideas, schemata or prototypes of higher density than reality or even art.

By moving away from the convention of depicting dreams naturalistically, Vasari chooses not to express their impressive verisimilitude. ${ }^{53}$ Yet his approach allows him to evoke a feature of oneiric vision that none of the traditional iconographies manage to convey: its discursiveness. Indeed, in being glyphic, Vasari's dream is both image and text. More than a single view, it is a story. We may contrast it with the nightmare that Albrecht Dürer recorded in graphic form some twenty years before. ${ }^{54}$ Dürer depicted it in its phenomenological aspect "wy ichs gesehen het", as it appeared to him. Inevitably, he had to resort to a long textual commentary beneath the image in order to make up for the picture's stillness. Vasari's strategy yields a different result. His phantasms are deployed as a sentence, translating the diegetic - and thereby cinematic - nature of dreams. We are almost reminded of a passage in C. G. Jung: "By a few hieroglyphic images strangely strung together, we express more in a few moments in dream language than could be expressed by ordinary language over the course of several days." 55 The strategy also captures the insuperable complexity of oneiric experience. The unintelligibility of Vasari's dream, in that sense, fully partakes of its resonance.

\section{Illustrations}

Fig. 1: Giorgio Vasari:Allegory of a Dream. Pen and brown ink, heightened with white, on blue paper, 19,2 X 39,4 cm, ca. 1541-1545. Chatsworth: The Devonshire Collection [( Devonshire Collection, Chatsworth].

Fig. 2: Cameo engraved with a Hippalektryon. Green jasper, $1,26 \times 1,05 \times 0,2 \mathrm{~cm}$, 1st-2nd century A.D. Rome: Dino and Ermesta Santarelli Foundation Collection [in: Angela

53 David Freedberg once argued that all the traditional pictorial methods for depicting the apparition of a dream (surrounding it by a cloud, altering its colour, etc) are ultimately failures, because "we know from experience that one of the essential properties of the figures we see in our dreams is that they seem to participate to the same level of reality as ourelf. our dreams is that they seem to participate to the same level of reality as ourself". See Freedberg: Images dans les rêves, p. 37.

54 Traumgesicht (1525), Vienna: Kunsthistorisches Museum.

55 C. G. Jung: Dream Interpretation Ancient and Modern. Ed. by John Peck, Lorenz Jung, and Maria Meyer-Grass. Transl. by Ernst Falzeder. Princeton: Princeton University Press, 2014, p. 51.
Gallottini (ed.): La glittica Santarelli ai Musei Capitolini: Intagli, cammei e sigilli. Rome: Artemide, 2012, no. 268, p. 171].

Fig. 3: The figs. 43-44 of Jurgis Baltrusaitis's Le Moyen-Âge fantastique, Paris: Flammarion, 1983 , originally published in 1955 .

Fig. 4: Battista Dossi: The Night. Oil on canvas, 82 x $149,5 \mathrm{~cm}, 1544$. Dresden: Gemäldegalerie [@ Gemäldegalerie Alte Meister, Staatliche Kunstsammlungen Dresden. Photograph: Elke Estel and Hans-Peter Klut].

Fig. 5: Illustration from Hypnerotomachia poliphili, Venice: Aldus Manutius, 1499, p. p-viv [in: Francesco Colonna: Hypnerotomachia Poliphili. Ed. by Giovanni Pozzi and Lucia A. Ciapponi. Padua: Antenore, 1964, vol. x, p. 238].

Fig. 6: Ancient cameo reproduced in Jurgis Baltrusaitis's Le Moyen-Âge fantastique, described as "Bêtes antiques dans la coquille" [in: Jurgis Baltrusaitis: Le Moyen-Âge fantastique. Paris: Flammarion, 1983, p. 52].

\section{Bibliography}

\section{Primary sources}

Agrippa, Heinrich Cornelius: Della vanità delle scienze [De incertitudine et vanitate scientiarum et artium]. Transl. by Lodovico Domenichi. Venice: Giovanni Farri \& fratelli, 1547.

Baudelaire, Charles: Correspondance. Ed. by Claude Pichois and Jean Ziegler. Paris: Gallimard, 1973.

Derrida, Jacques: Writing and Difference. Transl. by Alan Bass. London: Routledge, [1978] 2001.

Freud, Sigmund: The Basic Writings of Sigmund Freud. Transl. by A. A. Brill. New York: The Modern Library, 1938.

Freud, Sigmund: The Standard Edition of the Complete Psychological Works of Sigmund Freud. Transl. by James Strachey. Ed. by James Strachey, Anna Freud, Alix Strachey and Alan Tyson. London: Vintage, 2001.

Horapollo: The Hieroglyphics of Horapollo. Ed. by George Boas Princeton: Princeton, 1993. Hypnerotomachia poliphili. Venice: Aldus Manutius, 1499

Hypnerotomachie, ou Discours du songe de Poliphile. Paris: Jacques Kerver, 1546.

Jung, C. G.: Analytical Psychology: Its Theory and Practice: the Tavistock Lectures. Ed. by E. A. Bennet, Mary Barker and Margaret Game London: Routledge \& Kegan Paul, 1968. Jung, C. G.: Dream Interpretation Ancient and Modern. Transl. by Ernst Falzeder. Ed. by John Peck, Lorenz Jung and Maria Meyer-Grass Princeton: Princeton University Press, 2014.

Macrobius: Commentary on the Dream of Scipio. Transl. by William Harris Stahl. New York: New York, 1966.

Valeriano Bolzani, Pierio: Hieroglyphica sive de sacris Aegyptiorum literis commentarii. Basel: Michael Isengrin, 1556

Vasari, Giorgio: Le vite de' più eccellenti pittori, scultori e architettori, nelle redazioni del 155 e 1568. Ed. by Rosanna Bettarini and Paola Barocchi. Florence: Sansoni, 1966. Vocabolario degli Accademici della Crusca. Venice: Giovanni Alberti, 1612. 


\section{Secondary sources}

Aakhus, Patricia: Astral Magic in the Renaissance: Gems, Poetry, and Patronage of Lorenzo de' Medici. In: Magic, Ritual, and Witchcraft 3 (2008), issue 2

Acidini Luchinat, Cristina: La grottesca. In: Giulio Bollati and Paolo Fossati (eds.): Storia dell'arte italiana. Turin: Giulio Enaudi, 1982, pp. 161-200.

Assmann, Aleida: Traum-Hieroglyphen von der Renaissance bis zur Romantik. In: Gaetano Benedetti and Erik Hornung (eds.): Die Wahrheit der Träume. Munich: Fink, 1997, pp. 119-144.

Baltrušaitis, Jurgis: Le Moyen Âge fantastique. Antiquuités et exotismes dans l'art gothique. Paris: A. Colin, 1955 Barocchi, Paola (ed.): Scritti d'arte del Cinquecento. Milan, Naples: Riccardo Ricciardi
Editore, 1971.

Brunon, Claude-François: Signe, figure, language: les Hieroglyphica d'Horapollon. In ment Supérieure, 1982, pp. 29-47.
menaissance. Paris: Société d'Edition d'Enseigne-

Buck, Stephanie: Michelangelo's Dream. London: The Courtauld Gallery, 2010.

Bildenden Künste Bio Vasaris Vite. In: Wolfgang Brassat (ed.): Handbuch Rhetorik der Burke, Peter: The Cul Berin: de Gruyter, 2017, pp. 227-240.

tory. Ithaca, NY: Cornell History of Dreams. In: Peter Burke: Varieties of Cultural History. Ithaca, NX: Cornell University Press, 1997, pp. 23-42. Butor, Michel: Histoire extraordinaire. Essai sur un rêve de Baudelaire. Paris: Gallimard,
1961.

Cole, Michael: "The Demonic Arts and the Origin of the Medium". In: The Art Bulletin 84 (2002), issue 4

Cordellier, Dominique: Esquisse d'un portrait de l'artiste maniériste en génie du sommeil. In: Philippe-Alain Michaud (ed.): Comme le rêve le dessin: dessins italiens des XVIe et XVIIe siècles du Musée du Louvre. Paris: Centre Pompidou \& Musée dus des vre, 2005, pp. 136-153.

Corti, Laura, and Margaret Daly Davis: Giorgio Vasari: principi, letterati e artisti nelle carte di Giorgio Vasari. Florence: Casa Vasari, 198i.

Curran, Brian A.: The Egyptian Renaissance: The Afterlife of Ancient Egypt in Early Modern Italy. Chicago \& London: University of Chicago Press, 2007.

De Girolami Cheney, Liana: "Giorgio Vasari's Justice: Political Glory for the Farnese Family". In: Iconocrazia to (2016).

Dempsey, Charles: Disegno and Logos, Paragone and Academy. In: The Accademia Seminars: The Accademia di San Luca in Rome, c. 1590-1635. Ed. by Peter Memia SemiCASVA seminar papers. New Haven and London:Yale University Preter M. Lukehart.

Dempsey, Charles: Inventing the Renaissance Putto Yale University Press, 2010, pp. 43-54 Carolina Press, 2001.

Preaching in Alexandrisance Hieroglyphic Studies and Gentile Bellini's Saint Mark Preaching in Alexandria. In: Ingrid Merkel and Allen G. Debus (eds.): Hermeticism in the Renaissance. Washington: Folger, 1988, pp. 342-365.

Fenech Kroke, Antonella: Giorgio Vasari: la fabrique de l'allégorie. Florence: L. S. Olschki, 2011.

Freedberg, David: Images dans les rêves. In: Olivier Christin and Dario Gamboni (eds.): Crises de l'image religieuse: de Nicée II à Vatican II. Paris: Éditions de la Maison des sciences de l'homme, 1999, pp. 33-53.
Gallop, David (ed.): Aristotle on Sleep and Dreams. Warminster: Aris \& Phillips, 1996.

Gandolfo, Francesco: Il "Dolce Tempo": mistica, ermetismo e sogno nel Cinquecento. Rome: Bulzoni, 1978.

Gibson, Walter S.: "Bosch's Dreams: A Response to the Art of Bosch in the Sixteenth Century". In: The Art Bulletin 74 (1992), issue 2.

Giehlow, Karl: The Humanist Interpretation of Hieroglyphs in the Allegorical Studies of the Renaissance with a Focus on the Triumphal Arch of Maximilian I [1915]. Transl. by Robin Raybould. Leiden \& Boston: Brill, zor5.

Giglioni, Guido: Phantasms of Reason and Shadows of Matter: Averroes's Notion of the Imagination and Its Renaissance Interpreters. In: Anna Akasoy and Guido Giglioni (eds.): Renaissance Averroism and its Aftermath: Arabic Philosophy in Early Modern Europe. Dordrecht: Springer, 2013, pp. 173-193.

Giuliano, Antonio, Nicole Dacos, and Ulrico Pannuti (eds.): II tesoro di Lorenzo il Magnifico: Le gemme. Florence: Sansoni, 1973

Gombrich, Ernst H.: Icones symbolicae: Philosophies of Symbolism and Their Bearing on Art. In: Ernst H. Gombrich: Symbolic Images. London: Phaidon, 1972, pp. 123-199.

Göttler, Christine: Vapours and Veils: The Edge of the Unseen. In: Christine Göttler and Wolfgang Neuber (eds.): Spirits Unseen: The Representation of Subtle Bodies in Early Modern European Culture. Leiden: Brill, 2008, pp. xv-xxvii.

Grafton, Anthony: Reforming the Dream. In: Christopher S. Celenza and Kenneth Gouwens (eds.): Humanism and Creativity in the Renaissance: Essays in Honor of Ronald G. Witt. Leiden: Brill, 2006, pp. 271-292.

Härb, Florian: The Drawings of Giorgio Vasari (1511-1574). Rome: Ugo Bozzi Editore, 2015.

Kanz, Roland: Die Kunst des Capriccio: kreativer Eigensinn in Renaissance und Barock. Munich: Deutscher Kunstverlag, 2002.

Labarthe, Patrick: Baudelaire et la tradition de l'allégorie. Genève: Droz, 1999.

Lapatin, Kenneth: Grylloi. In: Christopher Entwistle and Noël Adams (eds.): Gems of Heaven: Recent Research on Engraved Gemstones in Late Antiquity, c. AD 200-600. London: British Museum, 2011, pp. 88-98.

Mai, Ekkehard (ed.): Das Capriccio als Kunstprinzip: zur Vorgeschichte der Moderne von Arcimboldo und Callot bis Tiepolo und Goya. Vienna and Milan: Kunsthistorisches Museum Wien and Skira, 1996.

Michel, Simone: Die Magischen Gemmen. Zu Bildern und Zauberformeln auf geschnittenen Steinen der Antike und Neuzeit. Berlin: Akademie Verlag, 2010.

Morel, Philippe: Les grotesques. Paris: Flammarion, 1997.

Paoli, Marco: "Sognare nel Cinquecento. Saggio su un microgenere editoriale tra Rinascimento e Controriforma: i trattati sul sogno". In: Rara Volumina 18 (2011), issues 1-2.

Rabbi-Bernard, Chiara, Alessandro Cecchi, and Yves Hersant (eds.): Il sogno nel Rinascimento. Livorno: Sillabe, 2013

Ruvoldt, Maria: The Italian Renaissance Imagery of Inspiration. Cambridge: Cambridge University Press, 2004.

Saß, Maurice: Physiologien der Bilder: Naturmagische Felder frühneuzeitlichen Verstehens von Kunst, Berlin: de Gruyter, 2016.

Scholl, Dorothea: Von den "Grottesken" zum Grotesken: die Konstituierung einer Poetik des Grotesken in der italienischen Renaissance. Münster: Lit, 2004

Simons, Patricia: "The Incubus and Italian Renaissance Art". In: Source: Notes in the History of Art 34 (2014), issue 1. 

Vitellozzi, Paolo: Gemme e magia dalle collezioni del Museo archeologico nazionale
dell'Umbria. Perugia: Fabrizio Fabri Editore, 2010.

Warncke, Carsten-Peter: Die ornamentale Groteske in Deutschland, 1500-1650. Berlin: V. Spiess, 1979 . Zwierlein-Diehl, Erika: Antike Gemmen und ihr Nachleben. Berlin, New York: de Gruy-
ter, 2007.
Florence Fesnegu

\section{Le rêve inspiré de l'artiste au temps des Lumières: une création amoureuse}

Associer rêve et inspiration dans le cadre du processus créatif de l'artiste au XVIII ${ }^{e}$ siècle évoque immanquablement les œuvres de Johann Heinrich Füssli et de Francisco de Goya. Le Cauchemar, réalisé par Füssli en 1781 et exposé à la Royal Academy en 1782, connaît un succès immédiat, encore accru par les gravures de Thomas Burke, diffusées et copiées à travers toute l'Europe. 'Le sommeil de la raison engendre des monstres de Goya connaît un sort identique après sa publication dans le recueil de quatre-vingt gravures intitulé Los caprichos, en 1799. Ces œuvres marquantes viennent clôturer le XVIII siècle et se font les hérauts du $\mathrm{XIX}^{\mathrm{e}}$ siècle romantique en mettant en exergue un lien indissociable entre rêve et création artistique. Cependant, l'utilisation du rêve comme source d'inspiration artistique ne fait que tardivement son entrée dans la peinture du $\mathrm{XVII}^{\mathrm{e}}$ siècle et les exemples, pour être emblématiques, n'en sont pas moins rares. Tous les pays européens ne sont pas touchés de la même manière par l'expression onirique du geste créatif et rares sont les artistes de la France des Lumières à lui avoir réservée une place significative dans leur production, à l'exception notoire de Watteau et de Fragonard. L'un avec son Rêve de lartiste et l'autre avec sa Fontaine d'amour donnent corps à une création inspirée par les songes. ${ }^{2}$ Revendiquer une création qui devrait l'essentiel de son existence au rêve qui l'a inspiré, se heurte en France à une triple difficulté culturelle, méthodique et philosophique. En premier lieu, la peinture est un art d'imitation qui doit son élévation à la représentation d'un beau idéal, lequel nécessite que le peintre choisisse dans la nature ce qui est le plus parfait, tel Zeuxis choisissant pour modèle les plus belles jeunes filles de Crotone. En second lieu le génie par définition inspiré - se doit d'être doté d'une énergie créatrice, domptée ensuite par une raison organisatrice : ces deux étapes successives témoignent d'une recherche intellectuelle intense et maîtrisée qui contraste avec l'image du paisible rêveur laissant libre cours à ses divagations. Enfin les rêves sont essen-

Andrei Pop : Antiquity, Theatre, and the Painting of Henry Fuseli. Oxford : Oxford University Press, 2015, p. 86-87.

2 Au sujet de Watteau, voir la contribution de Marlen Schneider dans le présent ouvrage. 
7) Deutsche

Forschungsgemeinschaft

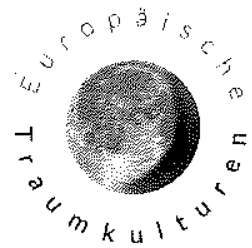

Umschlagabbildung:

Orpheus, c. 1903-1910. Odilon Redon (French, 1840-1916). Pastel; sheet: $68.8 \times 56.8 \mathrm{~cm}(271 / 16 \times 225 / 16 \mathrm{in}$. $)$. The Cleveland Museum of Art, Gift from J. H. Wade 1926.25
Bibliografische Information der Deutschen Nationalbibliothek

Die Deutsche Nationalbibliothek verzeichnet diese Publikation in der Deutschen Nationalbibliografie; detaillierte bibliografische Daten sind im Internet über

$$
\text { http://dnb.d-nb.de abrufbar. }
$$

Alle Rechte vorbehalten. Dieses Werk sowie einzelne Teile desselben sind urheberrechtlich geschützt. Jede Verwertung in anderen als den gesetzlich zugelassenen Fällen ist ohne vorherige schriftliche Zustimmung des Verlags nicht zulässig.

c) zo18 Wilhelm Fink Verlag, ein Imprint der Brill-Gruppe (Koninklijke Brill NV, Leiden, Niederlande; Brill USA Inc., Boston MA, USA: Brill Asia Pte Ltd, Singapore; Brill Deutschland GmbH, Paderborn, Deutschland)

\section{Internet: www.fink.de}

Einbandgestaltung: Evelyn Ziegler, München Herstellung: Brill Deutschland GmbH, Paderborn

ISBN $97^{-3-3-7705-6329-6}$

\section{Inhoth}

Dank

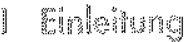

Marlen Schneider

Zum Verhältnis von Traum und künstlerischer Kreativität

Andrea Allerkamp

Erschütterung des Denkzwangs.

Zu Paul Valérys physiologischer Traumästhetik .

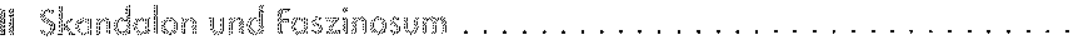

David Zagoury

Ut pictura somnium? On a Hieroglyphic Dream by Vasari.

Florence Fesneau

Le rêve inspiré de l'artiste au temps des Lumières:

une création amoureuse.

Marlen Schneider

Disturbing Inventions: Dream, Inspiration and Imagination in

the Age of Watteau . . . . . . . . . . . . . . . . . . . . .

Christian Quintes

Traumtheorie und Traumpoefik Friedrich von Hardenbergs (Novalis)

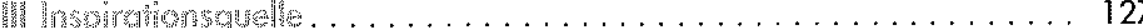

Magdalena Zorn

Erträumte Klangszenarien. Zum Traum als kompositorische

Inspirationsquelle im 19. und 20. Jahrhundert

Janina Sara Klein

Romantik, Surrealismus, Informel - Traum und Inspiration

im Werk von Bernard Schultze

Margot Dacheux/Giulio Boato

Le corps du rêve. Analyse des scènes de rêve

dans Mount Olympus de Jan Fabre. 
Joachim Harst

"Sueño dirigido«. Zur Poetologie des Traums bei

Dante Alighieri und J. L. Borges .................. 211

Linda Weiß

Spiegelungen - Das literarische Traumnotat

Jan Kameníks als Laboratorium.

Anna Rick

Traum: aufzeichnen in und um Wolfgang Herrndorfs Arbeit und Struktur. . .

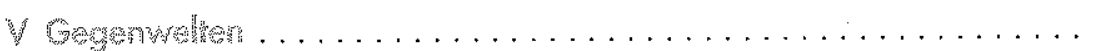

Tina Anderlini

La place du rêve dans l'œuvre d'Edward Burne-Jones

et sa réception critique.

Katina Baharova

Der Traum als Quelle götllicher Inspiration in der inoffiziellen Dịchtung

Russlands. Ol'ga Sedakova, Elena Švarc und

Gennadij Ajgi im Vergleich . . . . . . . . . . . . . . . . . 279

Yulia Mevissen

Alice im Wunderland und Kassandra treffen auf Walter Benjamin,

Ernsł Bloch und Dr. Freud: Intertextuelles Träumen in

Christa Wolfs Stadt der Engel.

Paris und Saarbrücken, November 2017

Der vorliegende Band ist aus einer interdisziplinären und internationalen Tagung für Nachwuchswissenschaftler/-innen hervorgegangen, die im Oktober 2016 an der Universität des Saarlandes im Rahmen des DFG-Graduiertenkollegs »Europäische Traumkulturen« veranstaltet wurde.

Zum Gelingen von Tagung und Publikation haben zahlreiche Kolleg/-innen beigetragen, denen an dieser Stelle herzlichst gedankt sei: Bei der Auswahl der Beiträge im Vorfeld der Veranstaltung und im anschließenden Peer-Review-Verfahren haben uns Bernard Dieterle, Claire Gantet, Susanne Goumegou, Johannes Grave, Sigrid Ruby, Hans-Walter Schmidt-Hannisa, Ricarda Schmidt, Dietrich Scholler und Kerstin Thomas mit ihrer Expertise unterstützt. Großer Dank gebührt der Koordination und den Hilfskräften des Graduiertenkollegs, insbesondere Elisabeth Huwer und Nina Beyer-Gartenhof, die beim Endlektorat wertvolle Hilfe geleistet haben. Zahlreiche Museen und andere Kultureinrichtungen haben uns kostenlos Bildrechte übertragen. Ermöglicht wurden sowohl die Tagung als auch der Band durch die großzügige Unterstützung der DFG.

Nicht zuletzt wollen wir den Autor/-innen und Vortragenden, aber auch den vielen weiteren interessierten und engagierten Tagungsteilnehmer/-innen danken, die das Thema »Traum und Inspiration « aus unterschiedlichsten Perspektiven beleuchtet, lebendige Diskussionen ermöglicht und unser Traumwissen auf vielfältige Weise bereichert haben. 


\section{Traum - Wissen - Erzählen}

Herausgegeben von

Stefanie Kreuzer, Christiane Solte-Gresser
Marlen Schneider, Christiane Solte-Gresser (Hg.)

\section{Traum und Inspiration}

Transformationen eines Topos in Literatur, Kunst und Musik 


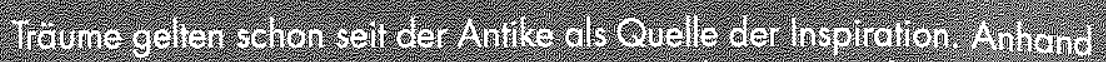

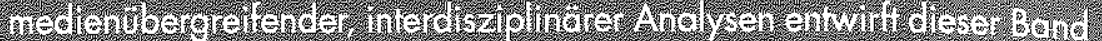

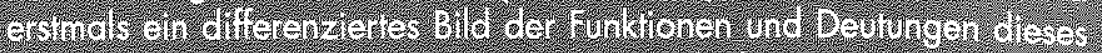

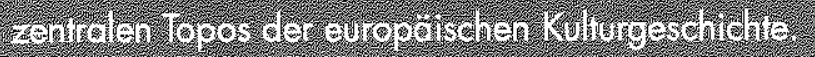

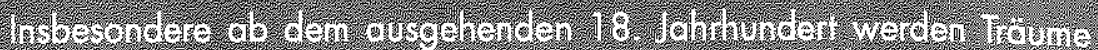

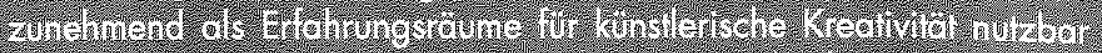

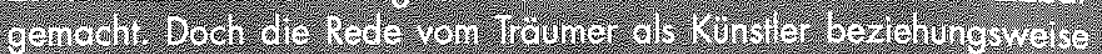

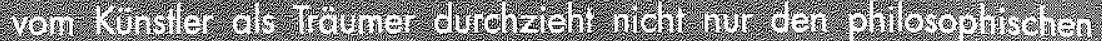

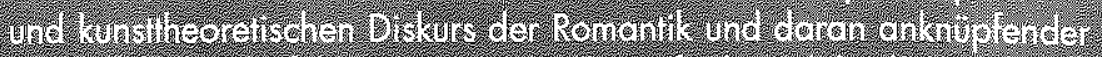

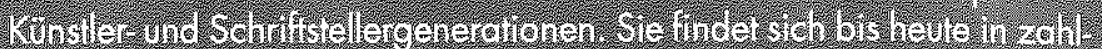

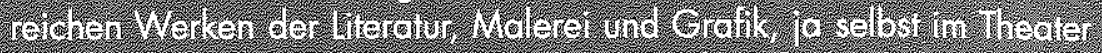

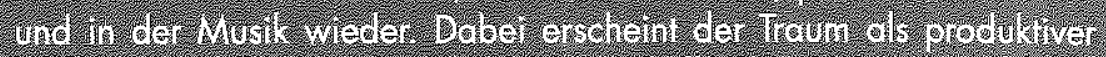

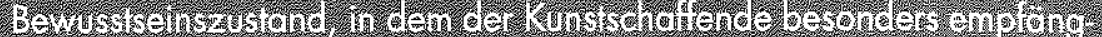

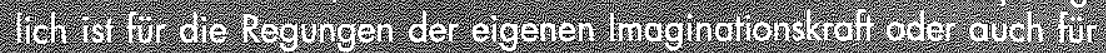

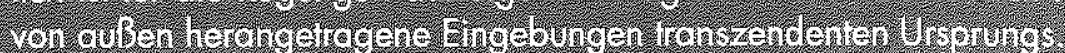

TRAUMWISSENERZAHLEN
Marlen Schneider | Christiane Solte-Gresser (Hg.)

\section{TRAUM UND INSPIRATION}

Transformationen eines Topos in Literatur, Kunst und Musik

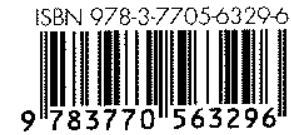

